\title{
EXCURSION ALONG THE NEW RAILWAY FROM BLACKHEATH TO BEXLEY HEATH.
}

\author{
SATURDAY, I 7 TH JUNE, I 893. \\ Diredor: T. V. Holmes, F.G.S. \\ (Report by ThE DiRector.)
}

Permission for our visit having been kindly given by $\mathrm{Mr}$. Rigby, the contractor, the party assembled at Blackheath and proceeded to the junction of the old and new lines, about a quarter of a mile east of Blackheath Station. There, a few feet south of the old line, a deep timbered excavation was seen. At one end of it the surface was seen to consist of Blackheath Pebble Beds. Beneath these, at a depth of 5 or 6 feet, were the shell-beds of the Woolwich Series, their thickness being about 8 feet. Below the shellbeds appeared yellowish and greenish sands containing pebbles towards their base, while at the bottom of the pit, at a depth of about 28 feet, the excavators had touched the light buff Thanet Sand.

Leaving this spot, the party crossed the road which traverses Blackheath Park Irom east to west. The railway is to run in a tunnel beneath this and another road, and there are at present (June, 1893) some deep open excavations on its southern side. The first visited had its more northerly end about 20 yards south of the road. At the bottom was the Woolwich Shell-bed, its top being about 27 feet below the surface. Above it were four or five feet of sand with partings, then Blackheath Pebble Beds, sandy towards their top and containing many shells towards their base. In some places they had become a hard, shelly conglomerate. Above, forming the surface, was I London Clay, having at its base a pebble-band of from about 8 to 15 inches, and attaining a maximum thickness of 6 or 7 feet. Here as elsewhere along our route, we saw irregular deposits of pebbles above the London Clay, close to the surface. A few yards further on, towards the southern face of the bank now being tunnelled, London Clay with its basement pebble-band was still seen to form the surface to a depth of two or three feet, but the Blackheath Pebble Beds had disappeared, and the basement bed of the London Clay rested upon I 3 or $\mathrm{I}_{4}$ feet of laminated sands with clayey partings, the Woolwich Shell-bed appearing at the bottom of the cutting beneath them. The Director pointed out the close resemblance between this last section and that at Loam Pit Hill, Lewishan, where the Blackheath Pebble Beds were entirely absent. Here,

OCTOYER, I 893 . 
N.W.

悹

.E. Railway

\section{1}

1

1

1

1

$1_{102}$ Blackheath Park

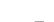

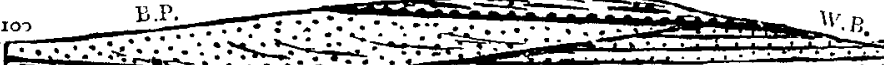

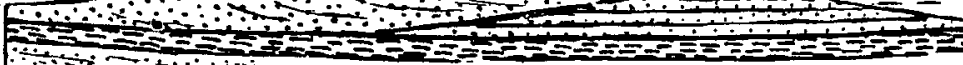

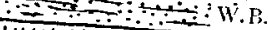

fia,

H11,1,1,1,1,1,1,T.S.

Figures 100, I1 8 show the height of the surface.

L.C. London Clay,

B.P. Blackheath Pebble Beds.

T.S. Thanet Sand. 
however (he added), a few yards to the north, the Blackheath Pebble Beds were visible, though only to a thickness of 14 or I 5 feet, or less than half that attained at Blackheath, about half-a-mile away to the north-west. But the most interesting feature of this Blackheath Park section was the way in which the London Clay rested unconformably, not merely on an eroded surface of the Blackheath Pebble Beds, but also on one of the Woolwich Beds. Mr. Whitaker had noted* that " in the western part of the London Basin this bed [London Clay] often rests on an uneven surface of the Reading Series," but had not mentioned any case in an eastern district. Here, however, in the hollow at the southern base of the gentle eminence on which they were standing, where the field drains approached the line, he (the Director) had seen in a drain the top of the Woolwich Shell-bed covered by a pebble band, which was evidently that at the base of the London Clay, as from that point eastward the whole of the cutting to its end south of Lower Kidbrooke Farm was in London Clay, irregular deposits of pebbles appearing on the surface. (Section I.)

Between I ower Kidbrooke Farm and the Woolwich and Eltham road south of Well Hall, the railway will be on an embankment. East of the road just named Blackheath Pebble Beds appear, at first in a bank south of the railway where they contain many oyster and other shells, and a few yards further on, in a cutting deepening eastward. Park Farm (Section 2) is a few yards north of the north-westerly corner of Eltham Park, and the high ground where the London Clay comes on is equally near to its north-eastern limit. Between these two spots the proportion of sand to pebbles was seen to increase very much eastward. When, however, we had passed through the central portion of the long cutting, in which the sides were of the overlying London Clay, and had reached the eastern border of Shepherdsleas Wood, we found that the pebbles decidedly predominated over the sand, Halting for a few moments at a spot near the north-western border of Eltham Park the Director remarked that a few yards southward the Blackheath Pebble Beds were known to have an average thickness of about 40 feet. In the well for the supply of the house at Eltham Park they were 44 feet, and in the shaft of the remarkable artificial cavern or denehole, discovered in Eltham Park in 1878 , they measured about 37 feet 9 inches. Excavations were made in Eltham Park in 1878 , by order of Mr. Thomas Jackson, the proprietor, in order to remedy a defect in the water supply. A leak was found, and the workmen were directed to trace the course of the water that had escaped. It was found to run into a disused brick drain, which ended at the top of a deep covered-in shaft. 'The top of the Chalk was I 6 feet below the surface, and the total depth of the shaft I 40 feet. It ended in a large chamber about fifty feet long by thirty

\footnotetext{
* "Geology of London," vol i, p. 238.
} 


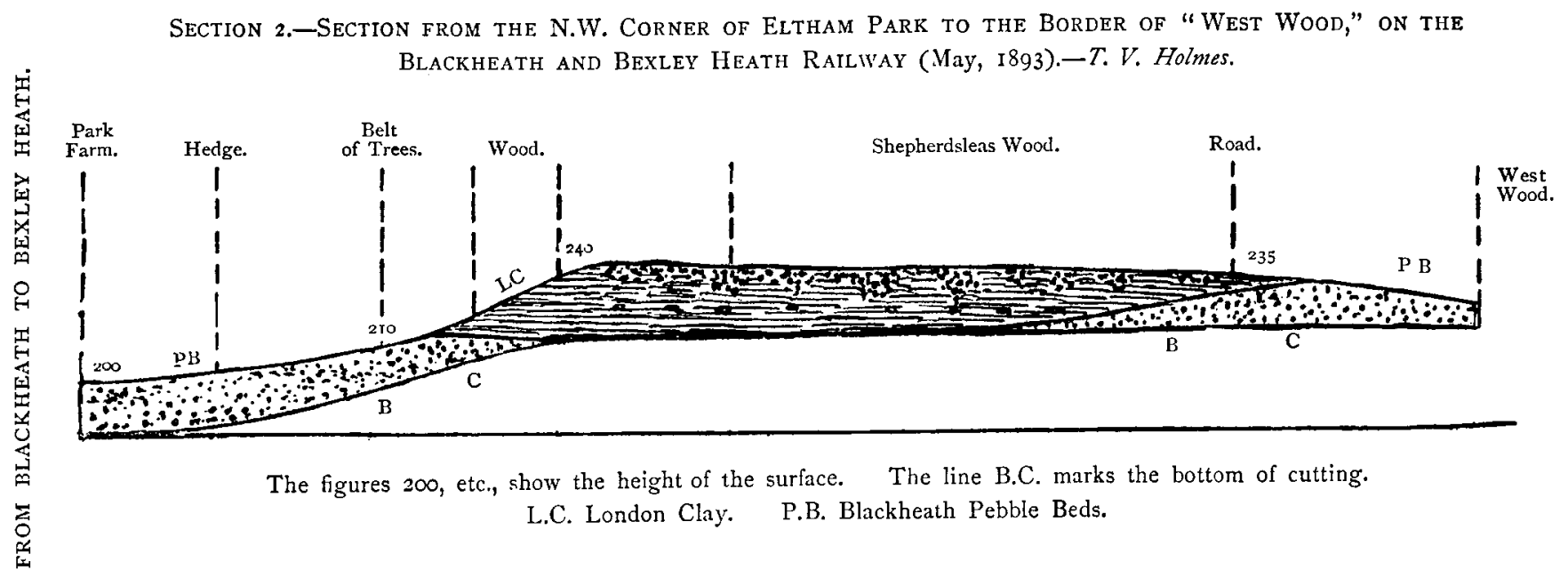

Scales: - Horizontal, 6 inches $=1$ mile; Vertical, 20 feet $=\frac{1}{4}$ of an inch. 
broad, and nine feet high, the roof being supported by three pillars of Chalk in the centre line of the chamber. This shaft was north of the house and south-east of the farm buildings, and on the eastern side of the road connecting them. Those wishing for further details he referred to a paper about it by Mr. W. M. Flinders Petrie in the Archaological Journal for 1878.

In the middle of the arable land, still known as "West Wood," the cutting ends and is replaced by an embankment. After tea at the Nag's Head Inn, Welling, the party pursued its way eastward. On the eastern side of the road ranging northward from Crooklog a small outlier of London Clay is shown on the Geological Survey map (x S.W.). The railway crosses this patch nearly at its centre. A few shallow pits along the course of the line were seen here and there, in and on both sides of this outlier. One within the outlier showed about 6 feet of London Clay, a more satisfactory section, the Director remarked, than any he had hitherto seen there. He added that his experience along that line generally had been that as the sections became clearer and better developed, so Mr. Whitaker's extreme care and accuracy had become more and more evident. Many months ago, when the Blackheath Park and Eltham Sections were very inferior in depth and clearness to what they had since become, he had thought that the new line would cause very considerable changes in the Geological Survey map. Had his early notions turned out to be correct, no discredit could rightly have attached to Mr. Whitaker on that account, the nature of the beds and the amount of evidence at his disposal being remembered. But the better the sections the more accurate had the Survey mapping shown itself to be.

Leaving the London Clay outlier, the party passed over ground giving evidence of pebble-beds at the surface, and came to a cutting gradually deepening eastward, and reaching a maximum of about 35 feet between Long Lane and Threecorner Wood. East of Conduit Wood the line is on an embankment. Towards the western end of the cutting, south of Long Lane Farms and west of Long Lane, a small fault was seen to cross the line, having a direction a little north of west and south of east, and a downthrow to the north, the position of the Woolwich Shell-bed being some feet lower on the northern than on the southern side of the line. Between Long Lane and Threecorner Wood there were on the average about 16 or 17 feet of Blackheath Pebble Beds above 13 or $\mathrm{I}_{4}$ feet of Woolwich Beds, the greenish or yellowish sands beneath the shell-bed being more or less visible towards the bottom of the cutting. Where the line crosses Threecorner Wood there was much slipped ground, owing chiefly to the presence of small faults. Towards the eastern boundary of Conduit Wood the cutting is succeeded by an embankment based upon Thanet Sand, and there are no more 
sections along the course of the new line, which joins the older one about midway between Erith and Dartford. The party walked along this embankment as far as the road on the eastern side of the wood called the Neck, in order to see a denehole in the Thanet Sand at the foot of the northern slope of the embankment, and a few yards west of the Neck. Then, either by way of Northumberland Heath or of Perry Street, the road to Erith was taken in order to catch the $8.3^{8}$ train for London.

\title{
REFERENCES.
}

Geslogical Survey Map, Sheet I S.W. (Drift Edition).

New Ordnance Survey Map, Sheet 27 I.

Whitaker W.- "The Geology of London." Mem. Gsol. Survey. I889.

\section{EXCURSION TO BASTED AND IGHTHAM.}

\author{
Saturday, 24th June, 1893.
}

Directors: W. J. Lewis Abbott, F.G.S., and E. T. Newton, F.R.S., F.G.S.

(Report by W. J. L. Апвотт.)

OWING to a misunderstanding as to the times of the trains, the members of the Association travelled in two parties. The first was joined by Mr. Abbott and the Kentish contingent of the Association at Sevenoaks, thence continuing the journey to Wrotham. Here the station yard has been excavated out of the Folkestone beds of the Lower Greensand. These beds are also worked for sand in pits adjoining to a depth of over fifty feet. The sand is of medium fineness, almost white, in places quite so, in others very prettily pseudo cross-bedded with iron-stainings. Nearer Sevenoaks the iron forms a large part of some of the beds. The upper twenty-five feet of the Folkestone beds near the London, Chatham, and Dover Railway at Sevenoaks contain large quantities of well-silicified sponges, echinoderms, and casts of bivalves. The Wrotham sands contain no fossils. Near this station, resting upon the Folkestone sands, is a bed of gravel about four feet thick, belonging to the Shode. At this the first halt was made, and the composition of the gravel notified. Mr. Abbott pointed out where he had discovered an ancient burial, and in the same urn with the burnt bones he had found a piece

OCTOBER, 1893 . 